\title{
EFFECT OF DIFFERENT CARBON SOURCES ON THE in vitro MULTIPLICATION OF Annona sp.
}

\author{
Efeito da fonte de carbono na multiplicação in vitro de Annona sp.
}

\author{
José Raniere Ferreira de Santana ${ }^{1}$, Renato Paiva $^{2}$, Ana Valéria de Souza ${ }^{3}$, Lenaldo Muniz de Oliveira ${ }^{4}$
}

\begin{abstract}
The Annonaceae family comprises approximately 2.300 species, some with significant commercial value. Although commercial plantations have suffered due to problems related to seedling production. As micropropagation is a viable technique for seedling production, the present work evaluated the effects of different carbon sources on in vitro bud induction in five Annonaceae species. Nodal segments obtained from plants of the Annona glabra, A. cauliflora, A. coriacea, A. bahiensis and Rollinia silvatica species were inoculated into solid WPM culture medium with $8.87 \mu \mathrm{M}$ BAP, $0.86 \mathrm{mM}$ of benomyl, and $87.64 \mathrm{mM}$ of the following carbon sources: glucose, sucrose, fructose, galactose, sorbitol and maltose. We evaluated the buds number, the length and weight of the largest bud, the number of expanded leaves per bud, the length of the largest leaf and the dry matter of the buds. No significant difference was observed among the different carbon sources used in terms of the number of produced buds; however, the length of the largest bud, the number of expanded leaves, the length of the largest leaf, and dry weight of the buds presented significant difference according to the studied speciesas well as the carbon sources used, with the lowest value being obtained with sorbitol. The results obtained here indicated that, except for sorbitol, any of the carbohydrates tested could be used in the in vitro multiplication protocols for A. bahiensis, A. cauliflora, A. coriacea, A. glabra and $R$. silvatica.
\end{abstract}

Index terms: Annonaceae, micropropagation, carbohydrates.

\section{RESUMO}

A família Annonaceae compreende, aproximadamente, mais de 2.300 espécies, algumas com ampla aceitação no mercado nacional. No entanto, o plantio comercial tem sido prejudicado, em razão das questões relacionadas à produção de mudas. Considerando que a micropropagação é uma técnica viável nesse contexto, conduziu-se este trabalho, com o objetivo de avaliar o efeito de diferentes fontes de carbono na indução de brotações in vitro em cinco espécies de anonáceas. Segmentos nodais obtidos de plantas de Annona glabra, A. cauliflora, A. coriacea, A. bahiensis e Rollinia silvatica, foram inoculados em meio à cultura WPM sólido $+8,87 \mu \mathrm{M}$ de BAP, 0,86 mM de benomil e 87,64 mM das seguintes fontes de carbono: glucose, sucrose, fructose, galactose, sorbitol e maltose. Avaliou-se o número de brotações, o comprimento e o peso da maior brotação, o número de folhas expandidas por brotação, o comprimento da maior folha e a matéria seca das brotações. Não houve diferença significativa entre as fontes de carbono para o número de brotações. Mas, para as variáveis comprimento das brotações, número de folhas expandidas, comprimento da maior folha e matéria seca das brotações, tanto as espécies estudadas como as fontes de carbono influenciaram significativamente as respostas, e os menores valores foram obtidos na presença de sorbitol. Os resultados obtidos indicam que, exceto o sorbitol, qualquer carboidrato pode ser utilizado em protocolos de micropropagação de A. bahiensis, A. cauliflora, A. coriacea, A. glabra e R. silvatica.

Termos para indexação: Annonaceae, micropropagação, carboidratos.

\section{(Received in june 14, 2010 and approved in november 11, 2010)}

\section{INTRODUCTION}

The family Annonaceae comprises approximately 132 genera and more than 2.300 woody species; approximately 50 species have edible fruits and some of them have commercial value. All of the species are originally from the Americas (predominantly from topical regions, with some occurring spontaneously in Brazil) and most are undomesticated (Jessup, 1988; Gardiazabal \& Rosemberg, 1993; Donadio et al., 1998, 2004; Pinto et al., 2005). According to São José et al. (1997) and Manica (2003), the most important species of Annonaceae cultivated in tropical regions are the "pinha" (Annona squamosa L.) and "graviola" (A. muricata L.), followed by "cherimoya" (A. cherimola Mill.) and "atemóia" (a hybrid between "pinha" and "cherimoya"). Other species, however, such as the "araticuns" (A. glabra, A. bahiensis and Rollinia silvatica), "marolo" (A. cauliflora) and "conde" (A. coriacea) have considerable commercial potential. Besides being edible in natura, some

\footnotetext{
'Universidade Estadual de Feira de Santana/UEFS - Departamento de Biologia/DBIO - Laboratório de Cultura de Tecidos - Avenida Presidente Dutra - s/n Santa Mônica - 44055-000 - Feira de Santana, BA - raniere@uefs.br

2Universidade Federal de Lavras/UFLA - Departamento de Biologia/DBI - Lavras, MG

${ }^{3}$ Empresa Brasileira de Pesquisa Agropecuária/Embrapa Semiárido - Petrolina, PE

${ }^{4}$ Universidade Estadual de Feira de Santana/UEFS - Departamento de Biologia/DBIO - Feira de Santana, BA
} 
Annonaceae fruits are processed industrial, while other plants have medicinal and insecticidal proprieties (Cordeiro et al., 2005).

Serious difficulties have appeared during attempts to obtain seedlings of Annonas sp. for extensive commercial plantings, principally due to intrinsic characteristics of these plants: the Annonaceae demonstrate protogynic dichogamy (Barros Neto, 2008); the time required to form seedlings through natural sexual propagation is very long due to their irregular germination and seed dormancy; and there is a high risk of pathogen transmission during vegetative propagation under field conditions (Soares Junior \& Martins, 2003; Pinto, 2005). According to Barros Neto (2008), the production of Annonaceae seedlings under field conditions is extremely expensive, and Rasai et al. (1995) noted that the process of grafting during in vivo propagation can result in serious problems in relation to seedling vigor, productivity, and disease resistance.

In vitro propagation has been used for seedlings production in many fruiting species, principally due to its advantages in terms of the possibility of obtaining large numbers of healthy seedlings in short periods of time (Grattapaglia \& Machado, 1998; Pasqual, 2001), and protocols for the micropropagation of a number of Annonaceae species have already been established (Rasai et al., 1995; Lemos \& Baker, 1996a,b, 1998; Padilla \& Encina, 2003; Nagori \& Purohit, 2004; Deccetti et al., 2008; Santana et al., 2008). There are still some factors, however, that can seriously interfere in the processes of in vitro organogenesis in the Annonaceae, especially in terms of bud induction in nodal segments.

Sucrose has been widely used as a carbon source for in vitro studies, and is generally considered the best carbohydrate source for promoting growth and differentiation. Some researchers have suggested, however, that different carbohydrates can have very distinct effects on tissue morphogenesis (Welander et al., 1989; Yu \& Reed, 1993; Lemos \& Baker, 1998; Skrebsky et al., 2004; Pati et al., 2006; Dobránszki \& Silva, 2010), making it necessary to evaluate their individual effects with each species. According to Mosaleeyanon et al. (2004), the effects of the types and concentrations of different carbohydrates on the growth and development of in vitro cultures are still relevant questions in micropropagation research, especially among woody species.

Considering the importance of Annonas species within the context of fruit cultivation in Brazil and the necessity of determining the best techniques for seedling production at commercial scales, the present work evaluated the effects of different carbon sources on in vitro bud induction in five species of Annonaceae.

\section{MATERIAL AND METHODS}

\section{General conditions of the experiment}

All experiments were carried out in the Plant Tissue Culture Laboratory of the Department of Plant Physiology at the Universidade Federal of Lavras in Lavras, Minas Gerais, Brazil. The explants were obtained from three year old plants matrices of the species Annona glabra L, Annona cauliflora Mart., Annona coriacea Mart., Annona bahiensis St. Hill., and Rollinia silvatica St. Hill. that had been maintained in a growth chamber under photoperiod 16:8 light cycle using gro-lux ${ }^{\odot}$ and cold-white lamps (130$170 \mu \mathrm{mol} \mathrm{m} \mathrm{m}^{-2} \mathrm{~s}^{-1}$ of photosynthetically active radiation), without temperature controls.

Lateral sections of semi-lignified stems were used as explant sources for in vitro establishment. In order to surface sterilized the stems, the leaves and node segments were held under running water for 20 minutes and the washed with a neutral detergent. The nodal segments were then cut into $10-15 \mathrm{~mm}$ lengths containing a single bud and immersed in $70 \%(\mathrm{v} / \mathrm{v})$ alcohol for 1 minute, followed by immersion for 15 minutes in a solution of sodium hypochlorite ( $1 \%$ of active chlorine) and a few drops of detergent. The explants were then washed five times in sterile distilled water before in vitro inoculation.

\section{Effects of different carbon sources on bud induction in nodal segments of Annonaceae}

Nodal segments of A. bahiensis, A. cauliflora, A. coriacea, A. glabra, and $R$. silvatica were inoculated into test tubes $(25 \times 150 \mathrm{~mm})$ containing $10 \mathrm{~mL}$ of WPM culture medium (Lloyd \& McCown, 1980) solidified with $7 \mathrm{~g} \mathrm{~L}^{-1}$ of agar, and supplemented with $8.87 \mathrm{mM}$ of BAP, $0.86 \mathrm{mM}$ of benomyl, and $87.64 \mathrm{mM}$ of one of the following carbon sources: glucose, sucrose, fructose, galactose, sorbitol, or maltose.

The $\mathrm{pH}$ of the culture medium was adjusted to 5.7 before autoclaving at $121^{\circ} \mathrm{C}$ for 15 minutes; after autoclaving the tubes were cooled inclined at 30 to $45^{\circ}$. One nodal segment was inoculated into each tube and these were sealed with a plastic cap and PVC wrap. The tubes were maintained in a growth room at $25 \pm 3^{\circ} \mathrm{C}$ under photoperiod 16:8 light cycle with $45-56 \mu \mathrm{mol} \mathrm{m} \mathrm{m}^{-2} \mathrm{~s}^{-1}$ of photosynthetically active radiation provided by fluorescent lamps. At 21 and 42 days after inoculation the numbers of buds were noted, and at 42 days the lengths of the largest buds $(\mathrm{cm})$, the numbers of expanded leaves per bud, and the lengths of the largest leaves $(\mathrm{cm})$ were recorded. 
The delineation experimental used was casuality with all possible combinations of plant species and carbon sources ( 5 species x 6 carbon sources), with 4 repetitions of 4 tubes per plot. The Tukey test was utilized software sisvar (Furtado, 2000).

\section{RESULTS AND DISCUSSION}

In vitro inductions of multiple buds in nodal segments of A. bahiensis, A. cauliflora, A. coriacea, A. glabra and $R$. silvatica were observed to be significantly different when using different carbon sources (glucose, sucrose, fructose, galactose, sorbitol and maltose), and also was observed that this variable is genotypedependent. Twenty-one days after inoculation, $A$. cauliflora had significantly more buds (1.77); 42 days after inoculation A. bahiensis and A. cauliflora had the largest numbers of buds ( 3 and 2.23, respectively) (Table 1).

The establishment of effective micropropagation protocols for woody species is a laborious process, especially when compared to herbaceous species. The sterilization procedures used for the explants and the types of culture media and accessory compounds used (such as plant growth regulators, antioxidant and organic compounds, etc.) can directly influence the different in vitro growth and development phases of the species. Dilute culture media were found to benefit bud induction in woody species during the in vitro multiplication phase, principally when supplemented with cytokines. WPM supplemented with growth regulators has given very positive results, although other factors such as the plant genotype and the type of carbohydrate (and its concentration) can also influence in vitro induction of multiple buds (Assis \& Teixeira, 1998; Souza \& Pereira, 2007).

A carbon source must be provided in the in vitro culture medium as the explants are not able to photosynthesize sufficiently in this artificial environment to sustain their own growth and development. Sucrose (at concentrations between $58.42 \mathrm{mM}$ to $116.85 \mathrm{mM}$ ) has been the most widely used carbohydrate source for explant culturing, although other compounds such as glucose, fructose, and maltose at different concentrations may also give positive results, depending (principally) on the genotype being tested (Grattapaglia \& Machado, 1998; Nicoloso et al., 2003; Mosaleeyanon et al., 2004; Skrebsky et al., 2004; Pati et al., 2006; Rodrigues et al., 2006; Bandeira et al., 2007; Luo et al., 2009; Dobránszki \& Silva, 2010; Mohamed \& Alsadon, 2010).

According to Mosaleeyanon et al. (2004), the presence of sucrose in the culture medium is necessary for the initial growth and morphogenesis of buds and leaves that will be indispensable for subsequent photosynthetic activities. Dobránszki \& Silva (2010) noted that the responses of the different species to different carbohydrates in in vitro multiplication studies may be related to genotype dependent interactions, as well as to residual effects of the culture medium in which the species had been maintained.

In addition to the types of carbohydrate sources, their concentrations may also influence culturing success. According to Grattapaglia \& Machado (1998), sugar concentrations lower or higher than $58.42 \mathrm{mM}-116.85$ $\mathrm{mM}$ can cause chlorosis or explant deterioration, respectively, in in vitro cultures. The results obtained by Skrebsky et al. (2004) corroborated with these authors, as sucrose concentrations higher than $175.28 \mathrm{mM}$ were not beneficial to the in vitro cultivation of Pfaffia glomerata or of seven rose varieties (Pati et al., 2006). Positive responses for the in vitro development of the aerial portions of Dendrobium huoshanense and Tymus vulgaris were obtained by Rodrigues et al. (2006) and Luo et al. (2009) with sucrose, maltose, glucose and fructose concentrations below $175.28 \mathrm{mM}$ for the former species and with sucrose for the latter species respectively.

In terms of the variables of bud lengths, numbers of expanded leaves, lengths of the largest leaves, and dry weights of the buds, our results were significantly different for the different species studied as well as the different

Table 1 - Average numbers of buds 21 and 42 days after the inoculation of nodal segments of the species Annona bahiensis St. Hill., Annona cauliflora Mart., Annona coriacea Mart., Annona glabra L. and Rollinia silvatica St. Hill.

\begin{tabular}{|c|c|c|}
\hline Species & Numbers of buds 21 days after inoculation & Numbers of buds 42 days after inoculation \\
\hline A. bahiensis & $0.51 \quad b^{\mathrm{z}}$ & $3.00 \quad \mathrm{a}$ \\
\hline A. coriácea & $0.54 \mathrm{~b}$ & $0.79 \mathrm{~b}$ \\
\hline R. silvatica & $0.55 \mathrm{~b}$ & $0.58 \mathrm{~b}$ \\
\hline A. glabra & $0.84 \mathrm{~b}$ & $0.87 \quad b$ \\
\hline A. cauliflora & $1.77 \mathrm{a}$ & $2.23 \mathrm{a}$ \\
\hline
\end{tabular}

\footnotetext{
${ }^{\mathrm{z}}$ - Averages followed by the same lower case letter in each column do not differ at a $5 \%$ probability level by the Tukey test.
} 
carbon sources evaluated (Tables 2, 3, 4 and 5). However, the interaction species $\mathrm{x}$ carbon source was significant only for the lengths of the largest leaves (Table 4) and bud dry weights (Table 5). The largest buds were observed in the species $A$. coriacea and A. glabra $(25.3$ and $23.0 \mathrm{~mm}$ respectively) and the largest numbers of expanded leaves were seen in A. coriacea (5.33) (Table 2).

In relation to the carbon source, with the sorbitol exception, there were no significant differences among the different sugars in terms of bud lengths and the numbers of expanded leaves (Table 3). Sorbitol presented the lowest average for both variables. The numbers of buds observed in culture media supplemented with sorbitol were only one third of those obtained with glucose, sucrose, fructose, maltose or galactose.

Table 2 - Average values for the bud length ( $\mathrm{mm}$ ) and numbers of expanded leaves in nodal segments of the species Annona bahiensis St. Hill., Annona cauliflora Mart., Annona coriacea Mart., Annona glabra L., and Rollinia silvatica St. Hill..

\begin{tabular}{lrlll}
\hline Species & \multicolumn{2}{c}{ Bud length } & \multicolumn{3}{c}{$\begin{array}{c}\text { Numbers of } \\
\text { expanded leaves }\end{array}$} \\
\hline A. bahiensis & 13.3 & $\mathrm{~b}^{\mathrm{z}}$ & 2.54 & $\mathrm{~b}$ \\
A. coriacea & 25.3 & $\mathrm{a}$ & 5.33 & $\mathrm{a}$ \\
R. silvatica & 13.9 & $\mathrm{~b}$ & 2.81 & $\mathrm{~b}$ \\
A. glabra & 23.0 & $\mathrm{a}$ & 2.92 & $\mathrm{~b}$ \\
A. cauliflora & 14.9 & $\mathrm{~b}$ & 3.28 & $\mathrm{~b}$ \\
\hline
\end{tabular}

${ }^{z}$ - Averages followed by the same lower case letter in each column do not differ at a $5 \%$ probability level by the Tukey test.
Table 3 - Average values for bud length ( $\mathrm{mm}$ ) and numbers of expanded leaves per bud in nodal segments of Annona bahiensis St. Hill., Annona cauliflora Mart., Annona coriacea Mart., Annona glabra L. and Rollinia silvatica St. Hill. as a function of carbon source.

\begin{tabular}{lrlrl}
\hline Carbon source & \multicolumn{2}{c}{ Bud length } & \multicolumn{2}{c}{$\begin{array}{c}\text { Numbers of } \\
\text { expanded leaves }\end{array}$} \\
\hline Glucose & 22.1 & $\mathrm{a}^{\mathrm{z}}$ & $3.92 \mathrm{a}$ \\
Fructose & 20.3 & $\mathrm{a}$ & 3.97 & $\mathrm{a}$ \\
Sucrose & 19.7 & $\mathrm{a}$ & $3.92 \mathrm{a}$ \\
Maltose & 18.6 & $\mathrm{a}$ & $3.64 \mathrm{a}$ \\
Galactose & 18.4 & $\mathrm{a}$ & $3.30 \mathrm{a}$ \\
Sorbitol & 6.8 & $\mathrm{~b}$ & $1.50 \mathrm{a}$ \\
\hline
\end{tabular}

$z$ - Averages followed by the same lower case letter in each column do not differ at a $5 \%$ probability level by the Tukey test.

The results found in the present work differ from those reported by Borkowska \& Szczerba (1991). These authors studied the effect of sucrose, glucose, fructose and sorbitol on the in vitro growth of Prunus cerasus L. and they observed that sorbitol favored bud growth at concentrations similar to those used in the present study. Lemos \& Baker (1998), on the other hand, found no evidence of sorbitol transport in the Annonaceae; Annona sp. could not metabolize it or convert it to other forms, so that it tended to accumulate in the plant tissues and increase the osmotic potential of the cells. Sorbitol has, however, been cited as one of the most efficient carbohydrates for inducing multiple buds in apple explants (Dobránszki \& Silva, 2010).

Table 4 - Average lengths of the largest leaf buds (mm) on nodal segments of Annona bahiensis St. Hill., Annona cauliflora Mart nodal., Annona coriacea Mart., Annona glabra L., and Rollinia silvatica St. Hill. as a function of the carbon sources.

\begin{tabular}{|c|c|c|c|c|c|c|c|c|c|c|c|c|}
\hline \multirow{3}{*}{$\begin{array}{l}\text { Carbon } \\
\text { sources }\end{array}$} & \multicolumn{10}{|c|}{ Average length of the largest leaf } & \multirow{2}{*}{\multicolumn{2}{|c|}{ Average }} \\
\hline & \multicolumn{2}{|c|}{ A. glabra } & \multicolumn{2}{|c|}{ A. coriacea } & \multicolumn{2}{|c|}{ R. silvatica } & \multicolumn{2}{|c|}{ A. bahiensis } & \multicolumn{2}{|c|}{ A. cauliflora } & & \\
\hline & 23.5 & $\mathrm{~A}^{\mathrm{z}} \mathrm{a}^{\mathrm{y}}$ & 25.7 & $\mathrm{Aa}$ & 13.7 & $\mathrm{Aa}$ & 18.5 & $\mathrm{Aa}$ & 17.7 & $\mathrm{Aa}$ & 19.8 & A \\
\hline Sucrose & 23.5 & Aa & 24.5 & $\mathrm{Aa}$ & 13.7 & $\mathrm{Aa}$ & 12.5 & $\mathrm{Aa}$ & 16.5 & $\mathrm{Aa}$ & 18.1 & A \\
\hline Fructose & 32.0 & $\mathrm{Aa}$ & 13.5 & $\mathrm{ABb}$ & 10.0 & $\mathrm{Ab}$ & 11.7 & $\mathrm{Ab}$ & 13.2 & $\mathrm{Ab}$ & 16.1 & A \\
\hline Galactose & 29.2 & Aa & 3.7 & $\mathrm{Bb}$ & 12.7 & $\mathrm{Ab}$ & 14.5 & $\mathrm{Ab}$ & 11.2 & $\mathrm{Ab}$ & 14.3 & A \\
\hline Maltose & 24.2 & $\mathrm{Aa}$ & 14.5 & $\mathrm{ABab}$ & 12.5 & Aab & 9.7 & $\mathrm{Ab}$ & 22.5 & $\mathrm{Aab}$ & 16.7 & A \\
\hline Sorbitol & 0.0 & $\mathrm{Ba}$ & 5.5 & $\mathrm{Ba}$ & 5.0 & $\mathrm{Aa}$ & 4.0 & $\mathrm{Aa}$ & 8.2 & $\mathrm{Aa}$ & 4.5 & B \\
\hline Average & 22.1 & $\mathrm{a}$ & 14.6 & $\mathrm{~b}$ & 11.3 & $\mathrm{~b}$ & 11,8 & $\mathrm{~b}$ & 14.9 & $\mathrm{~b}$ & & \\
\hline
\end{tabular}


Table 5 - Dry weights of buds (mg) on nodal segments of Annona bahiensis St. Hill., Annona cauliflora Mart., Annona coriacea Mart., Annona glabra L., and Rollinia silvatica St. Hill. cultivated with different carbon sources.

\begin{tabular}{crlrlllllllll}
\hline \multirow{2}{*}{$\begin{array}{c}\text { Carbon } \\
\text { Source }\end{array}$} & \multicolumn{10}{c}{ A. glabra } & \multicolumn{10}{c}{ A. coriacea } & \multicolumn{1}{c}{ R. silvatica } & A. bahiensis & A. cauliflora & & \multirow{2}{*}{ Average } \\
\hline Glucose & 14.4 & AB $^{\mathrm{z}} \mathrm{b}^{\mathrm{y}}$ & 55.0 & $\mathrm{Ba}$ & 22.9 & $\mathrm{ABb}$ & 21.7 & $\mathrm{ABb}$ & 28.6 & $\mathrm{Bb}$ & 28.6 & $\mathrm{AB}$ \\
Sucrose & 14.3 & $\mathrm{ABb}$ & 90.6 & $\mathrm{Aa}$ & 20.6 & $\mathrm{ABb}$ & 22.5 & $\mathrm{ABb}$ & 20.8 & $\mathrm{Bb}$ & 33.8 & $\mathrm{~A}$ \\
Fructose & 20.5 & $\mathrm{ABa}$ & $39.0 \mathrm{~B}$ & $\mathrm{Ca}$ & 29.0 & $\mathrm{Aa}$ & 32.9 & $\mathrm{Aa}$ & 17.1 & $\mathrm{Ba}$ & 27.7 & $\mathrm{AB}$ \\
Galactose & 23.0 & $\mathrm{Aa}$ & $23.3 \mathrm{C}$ & $\mathrm{Da}$ & 19.9 & $\mathrm{ABa}$ & 20.3 & $\mathrm{ABa}$ & 13.1 & $\mathrm{Ba}$ & 19.9 & $\mathrm{~B}$ \\
Maltose & 10.2 & $\mathrm{ABb}$ & 45.8 & $\mathrm{BCa}$ & 35.0 & $\mathrm{Aa}$ & 40.1 & $\mathrm{Aa}$ & 37.8 & $\mathrm{Aa}$ & 33.8 & $\mathrm{~A}$ \\
Sorbitol & 3.4 & $\mathrm{Ba}$ & 7.7 & $\mathrm{Da}$ & 7.1 & $\mathrm{Ba}$ & 4.6 & $\mathrm{Ba}$ & 13.2 & $\mathrm{Ba}$ & 7.2 & $\mathrm{C}$ \\
\hline Average & 14.4 & $\mathrm{~b}$ & 43.6 & $\mathrm{a}$ & 22.5 & $\mathrm{~b}$ & 23.7 & $\mathrm{~b}$ & 21.8 & $\mathrm{~b}$ & & \\
\hline
\end{tabular}

${ }^{z}$ - Averages followed by the same upper case letter in each column do not differ at a 5\% probability level by the Tukey test. $\mathrm{y}$ - Averages followed by the same lower case letter in each line do not differ at a $5 \%$ probability level by the Tukey test.

Nicoloso et al. (2003) compared four different concentrations of five carbon sources to determine the best combinations for bud numbers and lengths in Pfaffia glomerata, and reported that sucrose elicited the best results at concentrations of 87.64, 131.46 and $175.28 \mathrm{mM}$. Similarly, Mohamed \& Alsadon (2010) found that 87.64 $\mathrm{mM}$ of sucrose gave the best results in terms of the numbers and lengths of buds produced on potato explants. Romano et al. (1995) observed that sucrose (87.64 mM) and glucose (222.01 $\mathrm{mM})$ were the best carbon sources during the proliferation phase of the species Quercus suber. Pati et al. (2006) reported that while sucrose was the most widely used carbohydrate source in the micropropagation of roses, positive results could also be obtained in some cases with glucose.

Considering that no differences were observed among the different carbon sources in terms of bud induction or bud length (except in the case of sorbitol) among the species of Annonaceae studied here, it appears that almost any carbohydrate can be used to substitute sucrose in the in vitro multiplication protocols of Annonas sp. However, due to the established use of the sucrose, its easy availability and its low cost, it will most likely continue to be the most widely indicated carbohydrate for in vitro seedlings production among the species studied.

The A. glabra species had the largest average leaf length among the species evaluated $(22.1 \mathrm{~mm})$, but there were no significant differences observed among the carbon sources glucose, sucrose, fructose, galactose and maltose for this variable at a 5\% level of probability; sorbitol had the lowest value $(4.5 \mathrm{~mm})$ for this variable (Table 4).
The dry weight average of the buds was influenced by the carbon source and differed most significantly for sorbitol which presented the lowest dry weight average in A. coriacea. The largest average dry weight values were seen with $A$. coriacea and, with exception of A. cauliflora, there were no significant gains in dry weight with the use of glucose, fructose, galactose, maltose or sorbitol in comparison with sucrose. The largest average dry weight values were obtained in media supplemented with sucrose or maltose ( $33.8 \mathrm{mg} / \mathrm{bud})$, but was not significantly different from glucose and fructose. The the lowest value ( $7.2 \mathrm{mg} / \mathrm{bud}$ ) was obtained in the culture medium supplemented with sorbitol, which clearly indicated that this sugar was not well metabolized by Annona sp. (Table 5).

These results differ from those reported by Welander et al. (1989), in which the greatest in vitro bud growth of apple explants was observed using sorbitol as the carbon source, but corroborate those of Luo et al. (2009) who reported the best development of the aerial portions of Dendrobium huoshanense in the presence of maltose and sucrose. Smaller number of buds were obtained in this latter species using glucose, and no buds at all were produced when the medium was supplemented with fructose. According to these authors, in spite of the common use of sucrose in growth media, maltose may offer advantages for in vitro morphogenesis in various species. Dobránszki \& Silva (2010) cited sorbitol as the best carbon source for the in vitro multiplication of apple explants and noted that maltose was prejudicial.

As such, it appears that specific studies with each different genotype will be necessary to determine the best 
carbon sources for the different developmental phases of Annonaceae explants during in vitro multiplication. The results presented here indicate that sucrose continues to be the most indicated carbon source for the in vitro cultivation of the species A. bahiensis, A. cauliflora, A. coriacea, A. glabra, and $R$. silvatica.

\section{CONCLUSIONS}

The in vitro multiplication of $A$. bahiensis, A. cauliflora, A. coriacea, A. glabra, and $R$. silvatica was similar in the presence of the different carbon sources tested, except in the case of sorbitol which presented the worst result.

\section{REFERENCES}

ASSIS, T.F.; TEIXEIRA, S.L. Enraizamento de plantas lenhosas. In: TORRES, A.; CALDAS, L.S.; BUSO, J.A. Cultura de tecidos e transformação genética de plantas. Brasília: Embrapa-SPI/Embrapa CNPH, 1998. v.1, p.261296.

BANDEIRA, J.M.; LIMA, C.S.M.; RUBINI, S.; RIBEIRO, M.V.; FALQUETO, A.R.; PETERS, J.A.; BRAGA, E.J.B. Diferentes tipos de vedações dos frascos e concentrações de sucrose na micropropagação de Thymus vulgaris L. Revista Brasileira de Biociências, Porto Alegre, v.5, n.2, p.472-474, 2007. Suplemento.

BARROS NETO, J.D. Conservação de polen de anonas comerciais. 2008. 78p. Dissertação (Mestrado em Agricultura tropical e subtropical)-Instituto Agronômico de Campinas, Campinas, 2008.

BORKOWSKA, B.; SZCZERBA, J. Influence of different carbon sources on invertase activity and growth of sour cherry (Prunus cerasus L.) shoot cultures. Journal of Experimental Botany, Oxford, v.42, n.240, p.911-915, 1991.

CORDEIRO, M.C.R.; PINTO, A.C.Q.; ANDRADE, S.M.R. Uses Annonas species. In: PINTO, A.C.Q. Annona species. Southampton: International Centre for Underutilised Crops; University of Southampton, 2005. p.41-47.

DECCETTI, S.F.C.; SOARES, A.M.; PAIVA, R.; CASTRO, E.M. Effect of the culture environment on stomatal features, epidermal cells and water loss of micropropagated Annona glabra L. plants. Scientia Horticulturae, Amsterdam, v.117, p.341-344, 2008.
DOBRÁNSZKI, J.; SILVA, J.A.T. Micropropagation of apple: a review. Scientia Horticulturae. Biotechnology Advances, Ottawa, v.28, n.4, p.462-488, July/Aug. 2010.

DONADIO, L.C.; MÔRO, F.V.; SERVIDONE A.A. Frutas brasileiras. 2.ed. Jaboticabal: Unesp, 2004. 248p.

DONADIO, L.C.; NACHTIGAL, J.C.; SACRAMENTO, C.K. do. Frutas exóticas. Jaboticabal: Unesp, 1998. 279p.

GARDIAZABAL, F.I.; ROSEMBERG, G.M. El cultivo del chirimoyo. Valparaíso: Universitarias de Valparaíso, 1993. $145 \mathrm{p}$.

GRATTAPAGLIA, D.; MACHADO, M.A. Micropropagação. In: TORRES, A.C.; CALDAS, L.S.; BUSO, J.A. Cultura de tecidos e transformação genética de plantas. Brasília: Embrapa-SPI/Embrapa-CNPH, 1998. v.1, p.43-76.

JESSUP, L.W. Australian Annonaceae in an Asian-Pacific context. Proceedings of the Ecological Society of Australia, Melbourne, v.15, p.249-257, 1988.

LEMOS, E.E.P.; BAKER, D.A. Shoot regeneration in response to carbon source on internodal explants of Annona muricata L. Plant Growth Regulation, Dordrecht, v.25, n.2, p.105-112, July 1998.

LEMOS, E.E.P.; BLAKE, J. Control of leaf abscission in nodal cultures of Annona squamosa L. Journal of Horticultural Science, Ashford, v.71, n.5, p.721-728, Sept. 1996a.

LEMOS, E.E.P.; BLAKE, J. Micropropagation of juvenile and mature Annona muricata L. Journal of

Horticultural Science, Ashford, v.71, n.3, p.395-403, May 1996b.

LLOYD, G.; MCCOWN, B. Use of microculture for production and improvement of Rhododendron spp. HortScience, Alexandria, v.15, p.415, 1980. Abstract 321.

LUO, J.; WAWROSCH, C.; KOPP, B. Enhanced micropropagation of Dendrobium huoshanense C.Z. Tang et S.J. Cheng through protocorm-like bodies: the effects of cytokinins, carbohydrate sources and cold pretreatment. Scientia Horticulturae, Amsterdam, v.123, p.258-262, 2009. 
MANICA, I. Taxonomia, morfologia e anatomia. In: . Frutas anonáceas: ata ou pinha, atemólia, cherimólia e graviola: tecnologia de produção, pós-colheita e mercado. Porto Alegre: Cinco Continentes, 2003. p.23-64.

MOHAMED, M.A.H.; ALSADON, A.A. Influence of ventilation and sucrose on growth and leaf anatomy of micropropagated potato plantlets. Scientia

Horticulturae, Amsterdam, v.123, p.295-300, 2010.

MOSALEEYANON, K.; SHA-UM, S.; KIRDMANADEE, C. Enhanced growth and photosynthesis of rain tree (Samanea saman Merr.) plantlets in vitro under a $\mathrm{CO}_{2}-$ enriched condition with decreased sucrose concentrations in the medium. Scientia Horticulturae, Amsterdam, v.103, p.51-63, 2004.

NAGORI, R.; PUROHIT, S.D. In vitro plantled regeneration in Annona squamosa L. through direct shoot bud differentiation on hypocotyl segments. Scientia

Horticulturae, Amsterdam, v.99, n.1, p.89-98, 2004.

NICOLOSO, F.T.; ERIG, A.C.; RUSSOWSKI, D. Efeito de doses e fontes de carboidratos no crescimento de plantas de ginseng brasileiro [Pfaffia glomerata (Spreng.) Pedersen] cultivadas in vitro. Ciência e Agrotecnologia, Lavras, v.27, n.1, p.84-90, 2003.

PADILLA, I.M.G.; ENCINA, C.L. In vitro germination of cherimoya (Annona cherimola Mill.) seeds. Scientia Horticulturae, Amsterdam, v.27, p.219-227, 2003.

PASQUAL, M. Cultura de tecidos. Lavras: UFLA/ FAEPE, 2001.

PATI, P.K.; RATH, S.P.; SHARMA, M. In vitro propagation of rose: a review. Biotechnology Advances, Ottawa, v.24, p.94-114, 2006.

PINTO, A.C.Q. Agronomy Annonas species. In: Annona species. [S.1.: s.n.], 2005. p.71-127.

PINTO, A.C. de Q.; CORDEIRO, M.C.R.; ANDRADE, S.R.M. de; FERREIRA, F.R.; FILGUEIRAS, H.A. de;
ALVES, R.E.; KIMPARA, D.I. Annonas Species.

Sounthampton: University of Sounthampton, 2005. 268p.

RASAI, R.; GEORGE, A.P.; KANTHARAJAH, K. Tissue culture of Annona spp. (cherimoya, atemoya, sugar apple and soursop): a review. Scientia Horticultarae, Amsterdam, v.62, p.1-14, 1995.

RODRIGUES, M.M.; MELO, M.D.; ALOUFA, A.A.I. Propagação vegetativa in vitro e análise estrutural de macieira. Pesquisa Agropecuária Brasileira, Brasilia, v.41, n.1, p.171-173, 2006.

SANTANA, J.R.F.; OLIVEIRA, L.M.; PAIVA, R. Anatomia foliar de seis espécies de anonáceas cultivadas in vitro e em casa de vegetação. Ciência Rural, Santa Maria, v.38, n.8, p.2362-2365, 2008.

SÃO JOSÉ, A.R.; SOUZA, I.V.B.; MORAIS, O.M.; REBOUÇAS, T.N.H. Anonáceas produçãoe mercado: pinha, graviola, atemóia e cherimóia. Vitória da Conquista: DFZ/UESB, 1997. 310p.

\section{SKREBSKY, E.C.; NICOLOSO, F.T.; FERRÃO, G.E} Sucrose e período de cultivo in vitro na aclimatização ex vitro de ginseng brasileiro (Pfaffia glomerata Spreng. Pedersen). Ciência Rural, Santa Maria, v.34, n.5, p.14711477, 2004.

SOARES JUNIOR, E.J.; MARTINS, A.B.G. Clonagem de quatro espécies de Anonaceae potenciais como portaenxertos. Revista Brasileira de Fruticultura,

Jaboticabal, v.25, n.2, p.286-289, 2003.

WELANDER, M.; WELANDER, N.T.; BRACKMAN, A.S. Regulation of in vitro shoot multiplication in Syringa, Alnus and Malus by different carbon sources. Journal of Horticultural Science, Ashford, v.64, n.3, p.361-366, May 1989.

YU, X.; REED, B.M. Improved shoot multiplication of mature hazelnut (Corylus avellana L.) in vitro using glucose as a carbon source. Plant Cell Reports, Berlin, v.12, n.5, p.256-259, 1993. 